\title{
Characteristics of Mathematical Problems Posed by Teachers
}

\author{
Neila Tonin Agranionih iDa \\ Alina Galvão Spinillo iD b \\ Sintria Labres Lautert ${ }^{\mathrm{D}} \mathrm{b}$
}

\begin{abstract}
a Universidade Federal do Paraná, Programa de Pós- Graduação em Educação em Ciências e em Matemática, Programa de Pós-Graduação em Educação: Teoria e Prática de Ensino, Curitiba, PR, Brasil. ${ }^{\mathrm{b}}$ Universidade Federal de Pernambuco, Programa de Pós-Graduação em Psicologia Cognitiva, Recife, PE, Brasil
\end{abstract}

\begin{abstract}
Background: In science, posing problems is considered as important as solving them, however, school has explored little this type of activity. Objective: To examine the features of mathematical problems posed by elementary school teachers, analysing aspects related to the statement of the problems and the types of problems formulated. Design: Descriptive, qualitative research. Setting and participants: Eighty-seven teachers (45 teaching $1^{\text {st }}$ and $2^{\text {nd }}$ grades, and 42 teaching $3^{\text {rd }}, 4^{\text {th }}$, and 5 th grades of elementary school) attending a teacher education course promoted by the Municipal Secretary of Education of Curitiba. Data collection and analysis: The teachers were asked to formulate four problems involving addition, subtraction, multiplication, and division. The types of the quantities involved, the necessary information, the number of steps required for solving the problems, and the types of problems from the theory of conceptual fields were analysed. Results: The problems presented a clear language, sufficient information, required a single operation for their solution, involved discrete quantities, and presented few challenges. The problems of addition and subtraction involved situations of composition and transformation, those of multiplication were of simple proportion, and those of division were of partitive problems. Conclusions: The results suggest that the teachers have a limited conception about the formulation of problems, emphasising the need to promote teacher training courses that develop a greater understanding of the properties of the mathematical concept involved in the problems to be formulated and about resolution procedures to be adopted
\end{abstract}

Key words: Problem posing; Mathematical problems; Teachers; Problem characteristics; Problem types.

Corresponding author: Neila Tonin Agranionih. Email: ntagranionih@gmail.com 


\section{Características de Problemas Matemáticos Formulados por Professores}

\section{RESUMO}

Contexto: No campo das ciências formular problemas é considerado tão importante quanto resolver problemas, entretanto, esse tema tem sido pouco explorado nas atividades escolares. Objetivo: Examinar características de problemas matemáticos formulados por professores do Ensino Fundamental, analisando aspectos relativos à construção do enunciado e aos tipos de problemas elaborados. Design: Pesquisa descritiva e qualitativa. Ambiente e participantes: Oitenta e sete professoras (45 lecionavam no $1^{\circ}$ e $2^{\circ}$ anos e 42 no $3^{\circ}, 4^{\circ}$ e $5^{\circ}$ anos do ensino fundamental) que frequentavam um curso de formação de professores promovido pela Secretaria Municipal de Educação de Curitiba. Coleta e análise de dados: As professoras foram solicitadas a formular quatro problemas envolvendo adição, subtração, multiplicação e divisão. Foram analisadas a natureza das quantidades envolvidas, a presença das informações necessárias, o número de passos requeridos para a resolução e os tipos de problemas a partir da Teoria dos Campos Conceituais. Resultados: Os problemas apresentavam linguagem clara, informações necessárias para sua resolução, uma única operação, quantidades discretas e poucos desafios para a resolução. Os problemas de adição e subtração envolviam situações de composição e transformação, os de multiplicação de proporção simples e os de divisão situações de partição. Conclusões: Os resultados sugerem que os professores possuem uma concepção limitada acerca da formulação de problemas, ressaltando-se a necessidade de promover cursos de formação docente que desenvolvam uma maior compreensão sobre propriedades do conceito matemático envolvido nos problemas a serem formulados e sobre procedimentos de resolução a serem adotados.

Palavras-chave: Formulação de problemas; Problemas matemáticos; Professores; Características de problemas; Tipos de problemas.

\section{INTRODUCTION}

Problem posing is an old subject in science. Singer, Ellerton and Cai (2013) comment-that, back in 1938, Einstein and Infeld had already stated that formulating a problem could be more essential than solving it, because it is a process that makes it possible to raise new issues, new alternatives, face old problems from a new angle, and marking real advances in science. Similarly, in the educational field, posing mathematical problems is considered as important as the ability to solve them. Its didactic value for learning mathematical concepts and problem solving strategies is emphasised, as well as providing the 
development of logical reasoning (Kilpatrick, 1987; Bonotto, 2013; Singer, Ellerton, \& Cai, 2013). It also stimulates the students' creativity, motivation, and autonomy when learning in general (Bonotto, 2013; Brown \& Walter, 2005; Sengul \& Katranci, 2014). This theme has interested scholars in mathematics education and psychology (Freudenthal, 1973; Polya, 1995; Silver, 1994; Singer, Ellerton, \& Cai, 2013; Spinillo, Lautert, Borba, Santos, \& Silva, 2017; Stoyanova \& Ellerton, 1996).

Problem posing, according to Silver (1994), refers to both generating new problems and the reformulating problems that have already been solved. The author comments on the different facets of problem posing: (i) an instance associated with creativity and exceptional mathematical skills; (ii) a typical activity of mathematicians; (iii) a method of teaching mathematical concepts and problem solving; and (iv) a means of motivating and creating a positive attitude of students towards mathematics.

The importance of the activity of problem posing is recognised in public policies, being present in educational proposals of several countries such as the United States, China, Italy, and Korea. In Brazil, the National Curricular Parameters for Mathematics - PCN (Brasil, 1997) recommended the posing of problems in the teaching of arithmetic operations with natural and rational numbers in elementary school, along with the analysis, interpretation, and resolution of problems. In the PCN for high school, this activity was mentioned as a competence to be developed, suggesting the elaboration of questions from students' identification of a problem, and their understanding of its verbal statement (Brasil, 2000).

The National Common Curricular Base - BNCC (Brasil, 2017, p. 471) reiterates these recommendations, indicating that in elementary school mathematics teaching should focus "on understanding concepts and procedures in their different fields and in the development of computational thinking, aiming at solving and formulating problems in different contexts." In high school, BNCC recommends that problem posing be considered a tool for mathematics learning, adding that: "In the case of problem solving and problem posing it is important to consider different contexts (relating both to mathematics itself, including those arising from technological development, as well as to other areas of knowledge)" (Brasil, 2018, p. 535). 
It is noteworthy that the comments made so far are about students' performance However, there is another aspect equally relevant, which is the posing of problems by teachers, as discussed below.

Investigations with students focus on experiences conducted in the classroom setting and more controlled research situations (Altoé \& Freitas, 2019; Chica, 2001; English, 1997; Lowrie, 2002; Medeiros \& Santos, 2007; Zunino, 1995). Besides providing examples of didactic activities, those studies reveal that: (i) problem posing is an unfamiliar activity, especially for students in the early years of elementary school; and (ii) students tend to reproduce typical single steps and computational problems very similar to those present in textbooks. However, by mastering this activity and getting familiar with the mathematical language in word problems, they can formulate-more complex and appropriate problems.

Many of the research conducted with teachers and prospective teachers are intervention studies that seek to develop their ability to pose problems and their understanding of mathematical concepts. Other studies analyse the characteristics of the problems they posed. The research reported here is included in this second group of investigations, continuing and expanding a

previous study conducted with teachers from the $1^{\text {st }}$ to the $9^{\text {th }}$ grade of elementary school (Spinillo et al., 2017).

\section{INTERVENTION STUDIES WITH TEACHERS}

Lavy and Shriki (2007) investigated the impact of an intervention based on problem posing activities on prospective teachers' mathematical knowledge and problem solving skills. The intervention was based on a teaching strategy called "What if not?" (WIN) originally proposed by Brown and Walter (1993), which consisted of a didactic sequence that involved solving the problem, analysing its characteristics, posing a new problem, and solving it. Despite the progress in the participants' mathematical knowledge, the same positive impact was not observed in relation to the ability to solve problems.

Crespo (2003) asked prospective teachers to propose problem posing activities to their students during a mathematics teacher education course. The data showed that at the beginning of the didactic experience, participants tended to formulate problems that students should solve individually and that required only a simple numerical computation to be solved. At the end of the experience, 
the didactic situations proposed by the prospective teachers became more collaborative and based on discussions among the students, being more effective than the individualised dynamics initially proposed.

Pelczer, Singer and Voica (2014) examined the effect of a teacher education program on the ability to pose and solve multiple-choice problems. The intervention consisted of formulating, analysing, and discussing appropriate multiple-choice problems, especially regarding the elaboration of alternatives involving distractors pertinent to a given concept. The activities carried out throughout the intervention were posted on an e-learning platform and analysed by the researchers. The results revealed that the participants' main difficulty was to formulate the alternatives to adapt them to students' possible interpretations. However, there was a progress in the ability to analyse mathematical problems and focus on the essential aspects of their formulation.

There are researchers, such as Elwan and Sultan (2016), for whom problem posing is part of problem solving and, therefore, it should not be treated separately. Based on this premise, the authors investigated whether the development of the ability to pose mathematical would positively impact problem solving. For this, two groups of participants were compared: prospective teachers who were taught to use strategies to formulate problems, and others, who did not have this experience. The main result was that problem posing skills promoted better performance in problem solving.

In general, intervention programs and experiences with problem posing seem to broaden the mathematical knowledge of the teachers or prospective teachers, as well as their ability to formulate and solve problems. The underlying idea derived from those studies is that this would impact the promotion of more profitable didactic activities that would facilitate students' mathematics learning.

\section{RESEARCH ON TEACHERS MATHEMATICAL KNOWLEDGE AND THE CHARACTERISTICS OF THE PROBLEMS THEY FORMULATE}

More frequent than intervention studies are research that examine teachers' and prospective teachers' ability to pose problems and the characteristics of the problems they pose. The results of those investigations 
bring important information about the possibilities and difficulties they present when performing this activity.

An example is Leung and Silver's research (1997), in which the TAPP test (Test of Arithmetic Problem Posing) was applied to prospective elementary school teachers in two versions: one with and the other without numerical information. The data showed that participants were more successful in the quantitative than in the qualitative version of the test. The authors also observed that although most of the problems formulated presented the necessary information and involved multiple steps for their resolution (being considered complex problems), almost one third of the problems either did not contain all the information needed or were simple problems that required one single operation to be solved.

Şengül and Katranci (2014) asked prospective teachers to perform three tasks: (i) formulate problems from a problem presented that dealt with the concepts of ratio and proportion; (ii) describe the formulation process, reporting the difficulties they experienced; and (iii) suggest strategies that would help overcome the difficulties identified. The problems posed were clear, suitable to the principles related to the concepts involved, and, although simple, possible to be solved. The difficulties encountered resided in deciding on the suitable numerical expression to be used, formulating a problem different from the original problem presented as a model, associating the problem with the level of knowledge of the students for whom the problems were intended, and relating the problems to everyday life. To overcome such difficulties, the participants' main suggestions were solving the problem they posed before drafting its latest version, analysing the characteristics of the problems that served as a model, and obtaining further experience in problem solving.

The formulation of inexact division problems was examined by Ribeiro and Amaral (2015) with prospective teachers that consisted of three tasks: (i) solving inexact division sums; (ii) posing and solving a problem that could be solved through such operations, indicating to which school grade the problem would be appropriately presented; and (iii) analysing a set of solution procedures adopted by students when performing inexact division problems. Due to the focus of the present study, only the data referring to the first two tasks are considered. It was found that most of the correct answers given to the division sums did not guarantee the creation of a suitable problem, because, in many cases, the verbal statement of the problems did not have the necessary information that allowed them to be solved. The conclusion was that teachers, 
despite mastering the ability to solve inexact division sums, had difficulties in posing problems involving this concept.

Teachers who already teach in elementary school and high school have also been investigated, as illustrated in the following studies.

Cunha (2015), for instance, examined the knowledge of high school teachers regarding combinatorial reasoning. Participants were asked to (i) formulate different types of problems (combination, permutation, arrangement, and Cartesian product problems); (ii) identify similarities and differences between them; and (iii) pose problems based on the invariant principles that characterise each of these types. Not all problems the participants posed were combinatorial and even those that were, presented misconceptions, especially those that were Cartesian product problems. Participants also had difficulties in differentiating the types of combinatorial problems. The main conclusion was that, despite the teaching experience, participants had limited knowledge about the properties that characterise each type of combinatorial problems.

Souza and Magina (2017) asked elementary school teachers to pose multiplication and division problems. Most of the problems were of multiplication involving discrete quantities, and the partitive division problems. In general, the authors point to the low variability of the problems formulated by teachers.

As Souza and Magina (2017), Spinillo et al. (2017) investigated how teachers from the $1^{\text {st }}$ to the $9^{\text {th }}$ grades of elementary school posed multiplication and division problems. The results showed that despite formulating the problems appropriately, teachers had a limited view of this activity. They tended to formulate simple problems that required only one step to be solved, and problems that had little variability, characterised as simple proportion problems (multiplication) and partitive problems (division). Other situations specific to the conceptual field of multiplicative structures, such as those of multiple proportion and product of measures, were not posed by the teachers. A relevant finding was that the school grade in which the participants taught did not influence the characteristics of the problems. The authors attribute this limited conception to possible gaps in teacher education courses and to the high frequency of simple problems in textbooks and curriculum guidelines proposed to the early years of schooling. This seems to generate a prototypical representation of multiplication and division problems that is quite simplistic. 
Lee, Capraro, and Capraro (2018) investigated four mathematics teachers' mastery of the content knowledge and pedagogical knowledge. After an interview, the participants were asked to create a problem from a story and reformulate a mathematical problem they were presented. The results revealed that teachers were aware of the importance of problem posing and knew the difference between creating and reformulating a problem. They considered the activity of reformulation easier than the activity of posing a problem. The authors identified a discrepancy between the respondents' knowledge about problem posing revealed in the interview, and the problems they effectively posed. This finding demonstrated little articulation between content knowledge and practice. Teachers reported difficulties in incorporating problem posing into their teaching practices due to the short time available in the classroom, and lack of familiarity with this activity.

In general, the results of these studies indicate that teachers and future teachers find it difficult to create appropriate, diverse, and challenging problems. They also encounter practical difficulties in introducing problem posing in the classroom. Discussions about those results point to the little familiarity that teachers and prospective teachers have with this activity, since this theme is little addressed in initial and continuing education courses.

Faced with this scenario and considering the relevance of this topic for mathematics education, this research aims to examine the characteristics of mathematical problems posed by elementary school teachers, analysing aspects related to the verbal statement and the types of problems they formulate. The investigation continues and deepens the results obtained in a previous investigation with multiplication and division problems (Spinillo et al., 2017), as well as expands the analyses carried out by including addition and subtraction problems. This study seeks to examine whether the characteristics of the problems posed varied if the teacher taught in early school grades in which the emphasis is on the teaching of additive, or in more advanced school grades in which the emphasis is on the teaching of multiplicative concepts.

\section{METHOD}

\section{Participants}

Eighty-seven elementary school teachers (all of them were women) from state schools located in the city of Curitiba participated in the study. They 
were attending a teacher education course promoted by the Municipal Secretary of Education of Curitiba. The participants ${ }^{1}$ were divided into two groups: Group 1 formed by 45 teachers who teach in the $1^{\text {st }}$ and $2^{\text {nd }}$ grades, and Group 2 formed by 42 teachers who teach in the $3^{\text {rd }}, 4^{\text {th }}$, and $5^{\text {th }}$ grades.Considering the objectives of this study, the groups were thus constituted because in the first two grades of elementary school there is a greater emphasis on the teaching of additive concepts, while from the third year onwards the focus is on the teaching of multiplicative concepts.

\section{Materials and Procedure}

All participants were asked to formulate four mathematical problems in a collective application individually and in writing. The following instruction was given: "Formulate four mathematical problems: one of addition, one of subtraction, one of multiplication, and one of division." The order in which the problems were produced was free, as was the time allocated to perform the task that was applied in a single session.

The material used consisted of eraser, pencil and a sheet of paper with the printed instruction. Below this instruction, there was enough blank space for the writing of each of the four problems.

\section{RESULTS}

The problems posed by the teachers were analysed according to the clarity of the language used, to the presence of the necessary information for solving them, the nature of the quantities involved, the number of steps required

\footnotetext{
${ }^{1}$ The data presented and discussed here were collected with the teachers' due consent through the Free and Informed Consent Form (TCLE) and authorized by the institutions involved. Acta Scientiae is not responsible for any consequences and/or damages resulting to the participants. The fact that the teachers were all women was due to the availability of institution and people who volunteered to participate in this study.
} 
for their resolution, and the types of the problems. Comparisons were made between groups of participants and among operations in each group.

\section{Characteristics of the problems}

The teachers formulated 347 statements, of which $95.7 \%$ were word problems, $2.9 \%$ were descriptions of didactic procedures that could be presented in the classroom, and $1.4 \%$ were exercises $^{2}$, as exemplified below ${ }^{3}$ :

Example 1 (word problem): The school was invited for a visit to the museum. Participants will be $2^{\text {nd }} \mathrm{A}$ with 22 students and $2^{\text {nd }} \mathrm{B}$ with 25 students. How many students will attend the visit? (requested operation: addition)

Example 2 (didactic procedure): Construction of sets through manipulative materials to understand the multiplication tables. Construction of the multiplication table through a set of manipulative materials. (requested operation: multiplication)

Example 3 (exercise): Solve the additions, and each time you get a correct response, you win one piece of the puzzle. (requested operation: addition)

$$
\begin{array}{ll}
3+2 & 5+4 \\
0+3 & 8+2
\end{array}
$$

As shown in Table 1, most of the statements in both groups were word problems, this being observed in relation to each of the requested operations.

\section{Table. 1}

Number and percentage (in parentheses) of statements in each group of participants and each requested operation.

\section{GROUP 1}

\section{Requested operation}

\footnotetext{
${ }^{2}$ See Dante (2009) about the distinction between mathematical problem and mathematical exercise.

${ }^{3}$ In the presentation of the examples, the participants' writing was maintained.
} 


\begin{tabular}{|c|c|c|c|c|}
\hline & $\begin{array}{c}\text { Addition } \\
(n=45)\end{array}$ & $\begin{array}{c}\text { Subtractio } \\
n \\
(n=45)\end{array}$ & $\begin{array}{c}\text { Multiplicatio } \\
n \\
(n=45)\end{array}$ & $\begin{array}{c}\text { Division } \\
(n=45)\end{array}$ \\
\hline \multirow{2}{*}{$\begin{array}{c}\text { Word } \\
\text { problem }\end{array}$} & 42 & 43 & 41 & 41 \\
\hline & (93.3) & $(95.5)$ & (91.1) & (91.1) \\
\hline \multirow{3}{*}{$\begin{array}{l}\text { Didactic } \\
\text { procedure }\end{array}$} & 2 & 1 & 2 & 3 \\
\hline & $(4.4)$ & $(2.2)$ & $(4.4)$ & $(6.6)$ \\
\hline & 1 & 1 & 1 & 1 \\
\hline \multirow[t]{2}{*}{ Exercise } & $(2.2)$ & $(2.2)$ & $(2.2)$ & $(2.2)$ \\
\hline & \multicolumn{4}{|c|}{ GROUP 2} \\
\hline \multirow[b]{2}{*}{$\begin{array}{c}\text { Statemen } \\
\mathbf{t}\end{array}$} & \multicolumn{4}{|c|}{ Requested operation } \\
\hline & $\begin{array}{c}\text { Additio } \\
n \\
(n=42) \\
\end{array}$ & $\begin{array}{c}\text { Subtractio } \\
n \\
(n=42) \\
\end{array}$ & $\begin{array}{c}\text { Multiplication } \\
(\mathrm{n}=42)\end{array}$ & $\begin{array}{c}\text { Divisio } \\
n \\
(n=42)\end{array}$ \\
\hline \multirow{2}{*}{$\begin{array}{c}\text { Word } \\
\text { problem }\end{array}$} & 39 & 42 & 42 & 42 \\
\hline & (92.8) & (100) & (100) & $(100)$ \\
\hline \multirow{2}{*}{$\begin{array}{c}\text { Didactic } \\
\text { procedur } \\
\text { e }\end{array}$} & 2 & $\mathbf{0}$ & $\mathbf{0}$ & $\mathbf{0}$ \\
\hline & $(4.8)$ & $(0)$ & $(0)$ & $(0)$ \\
\hline \multirow[t]{2}{*}{ Exercise } & 1 & $\mathbf{0}$ & $\mathbf{0}$ & $\mathbf{0}$ \\
\hline & $(2.4)$ & $(0)$ & $(0)$ & $(0)$ \\
\hline
\end{tabular}

Note: Group 1: teachers of the $1^{\text {st }}$ and $2^{\text {nd }}$ grades of elementary school; Group 2: teachers of the $3^{\text {rd }}, 4^{\text {th }}$, and $5^{\text {th }}$ grades of elementary school.

Of the 321 problems formulated, $96.7 \%$ met the requested operations, while only $3.3 \%$ of them mistakenly involved the use of an operation different from that required. It was examined whether or not these 321 word problems could be solved. Problems considered impossible to be solved were those in which relevant information was omitted or those in which the relationships 
between the information were presented in a confusing way, as illustrated in the following examples:

Example 4 (problem impossible to solve): For Alice's tea, the mad hatter prepared the table with 16 cups, knowing that the set of cups has 3 parts. How many parts must he put on the table? (requested operation: multiplication)

Example 5 (problem impossible to solve): Pedro won 4.00. He bought a pastry. How much change did he get? (requested operation: subtraction)

It was found that $94.7 \%$ of the problems were possible to be solved. Table 2 shows that the distribution did not vary according to the group of participants nor according to the requested operation.

Table. 2

Number and percentage (in parentheses) of word problems that were possible and impossible to be solved in each group of participants and each operation.

\begin{tabular}{lcccc}
\hline \multirow{2}{*}{ Problems } & \multicolumn{4}{c}{ GROUP 1 } \\
\cline { 2 - 5 } & $\begin{array}{c}\text { Addition } \\
(\mathbf{n}=\mathbf{4 5})\end{array}$ & $\begin{array}{c}\text { Subtraction } \\
(\mathbf{n}=\mathbf{4 5})\end{array}$ & $\begin{array}{c}\text { Multiplication } \\
(\mathbf{n}=\mathbf{4 5})\end{array}$ & $\begin{array}{c}\text { Division } \\
(\mathbf{n}=\mathbf{4 5})\end{array}$ \\
\hline Possible & $\mathbf{3 9}$ & $\mathbf{3 9}$ & $\mathbf{3 9}$ & $\mathbf{4 0}$ \\
& $(86.7)$ & $(86.7)$ & $(86.7)$ & $(95.2)$ \\
Impossible & $\mathbf{1}$ & $\mathbf{2}$ & $\mathbf{2}$ & $\mathbf{1}$ \\
& $(2.2)$ & $(4.4)$ & $(4.4)$ & $(2.2)$ \\
\hline Problems & \multicolumn{5}{c}{ GROUP 2 } \\
\cline { 2 - 5 } & $\begin{array}{c}\text { Addition } \\
(\mathbf{n}=\mathbf{4 2})\end{array}$ & $\begin{array}{c}\text { Subtraction } \\
(\mathbf{n}=\mathbf{4 2})\end{array}$ & $\begin{array}{c}\text { Multiplication } \\
(\mathbf{n}=\mathbf{4 2})\end{array}$ & $\begin{array}{c}\text { Division } \\
(\mathbf{n}=\mathbf{4 2})\end{array}$ \\
\hline Possible & $\mathbf{3 4}$ & $\mathbf{3 7}$ & $\mathbf{3 8}$ & $\mathbf{3 8}$ \\
& $(81)$ & $(88.1)$ & $(90.1)$ & $(90.1)$ \\
Impossible & $\mathbf{3}$ & $\mathbf{4}$ & $\mathbf{2}$ & $\mathbf{2}$ \\
\hline
\end{tabular}


Note: Group 1: teachers of the $1^{\text {st }}$ and $2^{\text {nd }}$ grades of elementary school; Group 2: teachers of the $3^{\text {rd }}, 4^{\text {th }}$, and $5^{\text {th }}$ grades of elementary school.

As Spinillo et al. (2017), we also analysed whether the problem was adequate or inadequate. Adequate problems were those that provided a contextualisation or a reference for numerical information, explicitly contained the question to be answered, and presented unambiguous language. The inadequate problems, in turn, did not include the information considered necessary for their resolution and had linguistic inaccuracies that hindered their interpretation. It was found that all problems considered impossible to be solved had limitations regarding these aspects, as illustrated in the following examples:

Example 6 (ambiguous language): Pedro bought 6 lollipops and gave them to his 3 cousins. How many lollipops did each cousin get? (requested operation: division)

Example 7 (lack of clarity regarding the question to be answered): Under the blanket was the boat with 5 elves. Over time, the locomotive, the bear, the egg, and the clown arrived. Janice counted them all. What number did she find? (requested operation: addition)

Example 8 (numerical information inconsistent with the context of the problem; inappropriate verb tenses): At the school June party there will be the quadrille dance, in which 43 girls and 36 boys danced. How many children have danced in total? (requested operation: addition)

Example 9 (lack of information and ambiguous language): We have 3 flowers, two of them are red. How many are yellow? (requested operation: subtraction)

What can be noticed is that, in fact, the teachers of both groups produced problems that could be solved.

Another aspect considered for analyses was the number of steps required for solving the problem, which refers to the number of operations involved in the resolution process, which is ultimately related to the level of complexity of the problem. In the corpus analysed, the solution of the problems required one step, two steps, three or more steps. Examples: 
Example 10 (one-step problem): Carlos bought a package that had 15 candies for his 3 children to share. How many candies will each child receive? (requested operation: division)

Example 11 (two-step problem): Let's play Ladybug's game. We have 10 ladybugs and today 18 students came, how many pairs are we going to form so that everyone can play at the same time? Any Ladybugs left? How many? (requested operation: division)

Example 12 (problem of three or more steps): Maria Luiza is passionate about makeup, every month she buys items for her collection. Last month she bought a dozen and a half lipsticks, this month she bought half a hundred disposable brushes. Next month she will buy two and a half dozen mini eye shadows. How many items will she have at the end of three months? (requested operation: addition)

As presented in Table 3, most problems in both groups required a single step for their solution (Group 1: 92\% and Group 2: 88.7\%). Problems requiring two, three or more steps were very rare.

Table. 3

Number and percentage of problems (in parentheses) that required one, two and three or more steps for their solution in each group of participants.

\begin{tabular}{cccc}
\hline Groups & \multicolumn{3}{c}{ Number of steps } \\
\cline { 2 - 4 } & One & Two & $\begin{array}{c}\text { Three or } \\
\text { more }\end{array}$ \\
\hline Group 1 & $\mathbf{1 5 0}$ & $\mathbf{8}$ & $\mathbf{5}$ \\
$(\mathrm{n}=163)$ & $(92)$ & $(5)$ & $(3)$ \\
Group 2 & $\mathbf{1 4 0}$ & $\mathbf{8}$ & $\mathbf{1 0}$ \\
$(\mathrm{n}=158)$ & $(89)$ & $(5)$ & $(6)$
\end{tabular}

Note: Group 1: teachers of the 1st and 2nd grades of elementary school; Group 2: teachers of the $3 \mathrm{rd}$, 4th, and 5th grades of elementary school. 
This result indicates that, regardless of the school grade they teach, teachers tend to think in terms of a single operation for each problem, so that the problems were very simple, not bringing any challenge to the one who solves it. These aspects will be resumed in the final discussions.

It was also examined whether the quantities mentioned in the problems were discrete or continuous ${ }^{4}$. In most problems, the quantities were discrete, both in Group $1(89 \%)$ and Group $2(84 \%)$. Table 4 shows that there were no differences between problems with continuous and discrete quantities that could be attributed to the type of operation requested or to the groups of participants.

\section{Table. 4}

Number and percentage (in parentheses) of problems with discrete and continuous quantities in each group of participants and each operation.

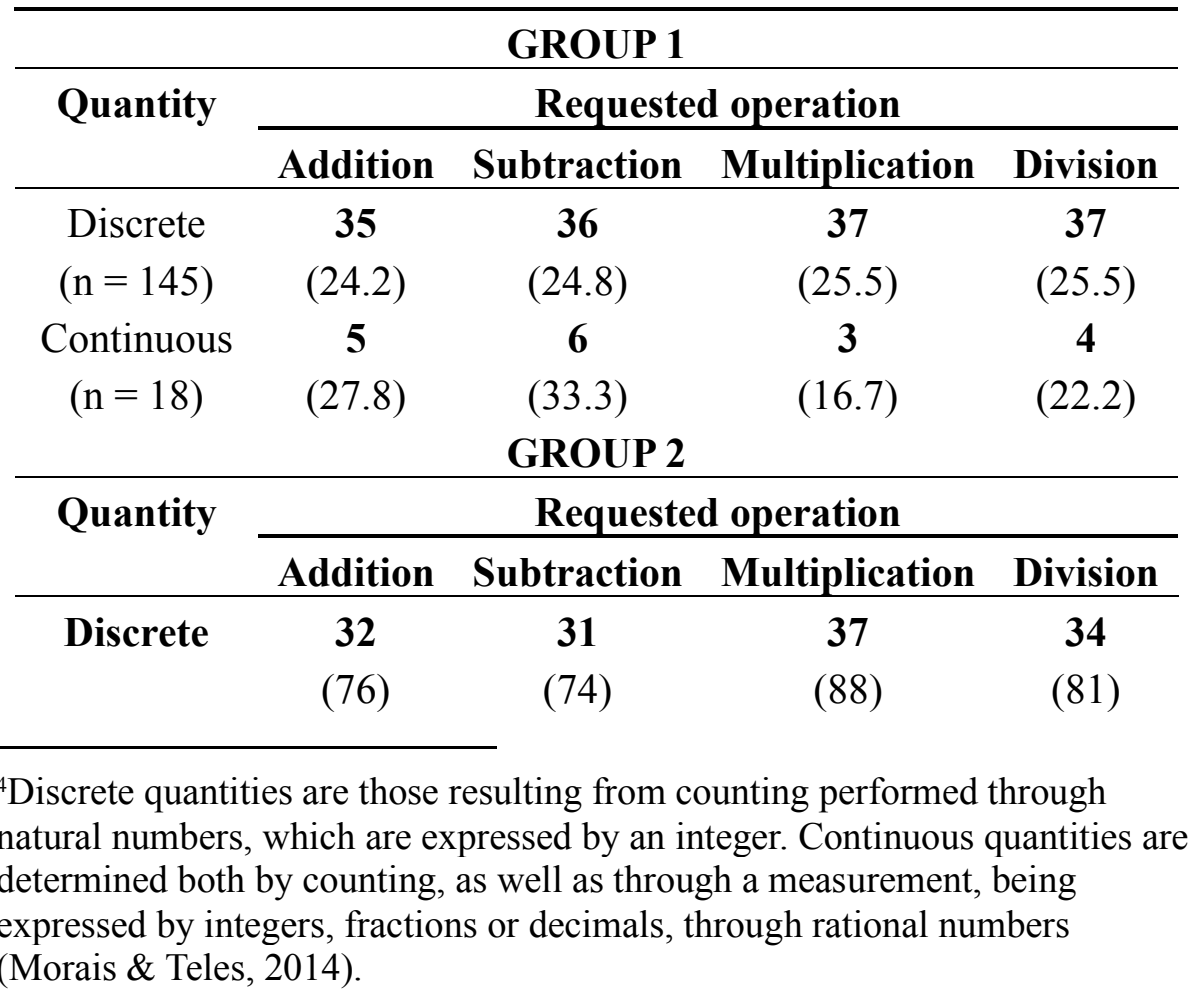


Continuous

Note: Group 1: teachers of the $1^{\text {st }}$ and $2^{\text {nd }}$ grades of elementary school; Group 2: teachers of the $3^{\text {rd }}, 4^{\text {th }}$, and $5^{\text {th }}$ grades of elementary school.

In general, the pattern of results is the same in both groups. In other words, the groups do not differ in relation to any of the aspects considered in the analysis of the characteristics of the problems formulated, nor do they vary according to the operations requested.

\section{The types of problems}

Based on the theory of conceptual fields of Vergnaud (1983, 1990, 2003), the problems were grouped in two blocks: one block concerning the problems of the additive structure (addition and subtraction) and the other, the problems of the multiplicative structure (multiplication and division). The typology adopted for additive problems was based on Vergnaud (2009), and the typology adopted for multiplicative problems were based on the classification proposed by Magina, Santos, and Merlini (2014) and Lautert, Castro-Filho, and Santana (2017), which, in turn, also have Vergnaud's classification as a theoretical basis.

\section{The types of addition and subtraction problems posed by the teachers}

The problems of addition and subtraction were classified into four types: composition, transformation, comparison, and composition of transformations. Examples:

Example 13 (composition problem): Marina won a dozen coloured pencils and 5 writing pencils. How many pencils did she get? (requested operation: addition)

Example 14 (composition problem): In a 3rd-grade classroom there are 31 students. Of these, 18 are girls. How many boys are there? (requested operation: subtraction) 
Example 15 (transformation problem): This week we will have our June party. To make it a very cool party, the school principal asked for gifts, and the class that brings the greatest amount of gifts will win a tour. The class of $1^{\text {st }}$ grade B had brought 15 gifts, in our last count, now the class brought 7 more gifts. How many gifts have been brought so far? (requested operation: addition)

Example 16 (transformation problem): Maria went fishing with her father on holiday. They managed to catch 24 fishes. But when they caught them in the box, 12 fishes jumped into the river again. How many fishes were left in the box? (requested operation: subtraction)

Example 17 (comparison problem): Carolina collects dolls, and her friend Maria too. Carolina has 15 dolls, and Maria has 10. How many dolls does Carolina have more than Maria? (requested operation: subtraction)

Example 18 (comparison problem): João is 4 years old, his sister Mariana is 12 years older than him. How old is she? (requested operation: addition)

Example 19 (composition of transformations): A dealership has 120 cars in its yard to sell. In May, this same dealership sold 7 cars in the first week. In the second week, it sold two. The third, it sold twice as much as in the first week, and the last week, there were no sales. How many cars did the dealership have end the month of May if it did not purchase any more cars for its fleet? (requested operation: subtraction)

Example 20 (composition of transformations): In the weeks preceding the June school party, the principal proposed an internal competition. The students in the 3rd-grade has scored 150 points in the first week, 320 points in the second week and 225 points in the last week. What was the total score obtained by the 3rd-grade class? (requested operation: addition)

The classification of problems was decided through discussion between two judges. As indicated in Table 5, in both the addition and subtraction operations, the most frequent types of problems formulated were those of 
composition and transformation. This was observed in both groups of participants. Comparison problems were rare, being absent in Group 1.

\section{Table. 5}

Number and percentage (in parentheses) of each type of addition and subtraction problems in each group of participants.

\begin{tabular}{|c|c|c|c|c|}
\hline \multirow{2}{*}{$\begin{array}{c}\text { Operatio } \\
\text { n } \\
\text { Requeste } \\
\text { d }\end{array}$} & \multicolumn{4}{|c|}{ GROUP 1} \\
\hline & $\begin{array}{c}\text { Compositi } \\
\text { on }\end{array}$ & $\begin{array}{c}\text { Transformat } \\
\text { ion }\end{array}$ & $\begin{array}{c}\text { Comparis } \\
\text { on }\end{array}$ & $\begin{array}{c}\text { Composition } \\
\text { of } \\
\text { Transformati } \\
\text { ons }\end{array}$ \\
\hline $\begin{array}{l}\text { Addition } \\
(\mathrm{n}=40)\end{array}$ & $\begin{array}{c}\mathbf{2 0} \\
(50)\end{array}$ & $\begin{array}{c}12 \\
(30)\end{array}$ & $\begin{array}{c}\mathbf{0} \\
(0)\end{array}$ & $\begin{array}{c}8 \\
(20)\end{array}$ \\
\hline $\begin{array}{c}\text { Subtracti } \\
\text { on } \\
(n=41)\end{array}$ & $\begin{array}{c}13 \\
(32)\end{array}$ & $\begin{array}{c}18 \\
(44)\end{array}$ & $\begin{array}{c}6 \\
(14)\end{array}$ & $\begin{array}{c}4 \\
(10)\end{array}$ \\
\hline & \multicolumn{4}{|c|}{ GROUP 2} \\
\hline $\begin{array}{c}\text { Operatio } \\
\text { n } \\
\text { Requeste } \\
\text { d }\end{array}$ & $\begin{array}{c}\text { Compositi } \\
\text { on }\end{array}$ & $\begin{array}{c}\text { Transformat } \\
\text { ion }\end{array}$ & $\begin{array}{c}\text { Comparis } \\
\text { on }\end{array}$ & $\begin{array}{c}\text { Composition } \\
\text { of } \\
\text { Transformati } \\
\text { ons }\end{array}$ \\
\hline $\begin{array}{l}\text { Addition } \\
(\mathrm{n}=37)\end{array}$ & $\begin{array}{c}17 \\
(46)\end{array}$ & $\begin{array}{c}7 \\
(19)\end{array}$ & $\begin{array}{c}1 \\
(3)\end{array}$ & $\begin{array}{c}12 \\
(32)\end{array}$ \\
\hline $\begin{array}{c}\text { Subtracti } \\
\text { on } \\
(n=41)\end{array}$ & $\begin{array}{c}20 \\
(49)\end{array}$ & $\begin{array}{c}13 \\
(32)\end{array}$ & $\begin{array}{c}7 \\
(17)\end{array}$ & $\begin{array}{c}1 \\
(2)\end{array}$ \\
\hline
\end{tabular}

Note: Group 1: teachers of the $1^{\text {st }}$ and $2^{\text {nd }}$ grades of elementary school; Group 2: teachers of the $3^{\text {rd }}, 4^{\text {th }}$, and $5^{\text {th }}$ grades of elementary school. 


\section{The types of multiplication and division problems posed by the}

\section{teachers}

Differently from the problems of additive structure, which were classified with the same typology for both the addition and subtraction operation, problems of multiplicative structure were classified according to two typologies: one related to multiplication problems and the other to division problems.

The multiplication problems were classified into the following types: simple proportion one-to-many, product of measures (rectangular and combinatorial configuration) and multiplicative comparison, as exemplified below:

Example 21 (simple proportion one-to-many): If on each day Mariana reads 3 pages of the book, how many pages does she read in a week? (requested operation: multiplication)

Example 22 (product of measures: rectangular configuration): Today our classroom is complete. We have 6 rows of desks with 5 students in each row. How many students do we have in the classroom today? (requested operation: multiplication)

Example 23 (product of measures: combinatorial): Mariana has a party to go to. She chooses, as an option, 4 skirts and 3 blouses. How many ways can she combine her outfits to rock the party? (requested operation: multiplication)

Example 24 (multiplicative comparison problem): Carlos has 6 toy cars. Pedro has twice that amount. How many toy cars does Pedro have? (requested operation: multiplication)

Table 6 shows that a simple proportion one-to-many problem was the most frequent type of multiplication problem formulated in both groups (Group 1: $68 \%$ and Group 2: $65 \%$ ). It is noteworthy that only one multiplication problem involved combinatorics.

Table. 6 
Number and percentage (in parentheses) of each type of multiplication problems in each group of participants.

\begin{tabular}{|c|c|c|c|c|}
\hline \multirow[b]{2}{*}{$\begin{array}{c}\text { Group } \\
\mathbf{s}\end{array}$} & \multicolumn{4}{|c|}{ Types of multiplication problems } \\
\hline & $\begin{array}{c}\text { Simple } \\
\text { proportio } \\
\text { n one-to- } \\
\text { many }\end{array}$ & $\begin{array}{c}\text { Product of } \\
\text { measures } \\
\text { Rectangular } \\
\text { configuratio } \\
\text { n } \\
\end{array}$ & $\begin{array}{c}\text { Product of } \\
\text { measures } \\
\text { Combinatori } \\
\text { al }\end{array}$ & $\begin{array}{c}\text { Multiplicativ } \\
\text { e } \\
\text { comparison }\end{array}$ \\
\hline $\begin{array}{c}\text { Group } \\
\mathbf{1} \\
(n=41)\end{array}$ & $\begin{array}{c}\mathbf{2 8} \\
(68)\end{array}$ & $\begin{array}{c}8 \\
(20)\end{array}$ & $\begin{array}{c}\mathbf{0} \\
(0)\end{array}$ & $\begin{array}{c}\mathbf{5} \\
(12)\end{array}$ \\
\hline $\begin{array}{c}\text { Group } \\
\qquad \begin{array}{c}2 \\
(n=40)\end{array}\end{array}$ & $\begin{array}{c}\mathbf{2 6} \\
(65)\end{array}$ & $\begin{array}{c}\mathbf{6} \\
(15)\end{array}$ & $\begin{array}{c}1 \\
(2.5)\end{array}$ & $\begin{array}{c}7 \\
(17.5)\end{array}$ \\
\hline
\end{tabular}

Note: Group 1: teachers of the $1^{\text {st }}$ and $2^{\text {nd }}$ grades of elementary school; Group 2: teachers of the $3^{\text {rd }}, 4^{\text {th }}$, and $5^{\text {th }}$ grades of elementary school.

When the operation of division was requested, the problems were classified into two types: partitive and quotitive ${ }^{5}$. Examples:

Example 25 (partitive): In another puzzle game, the teacher brought 12 cards to play with three children. How many cards will each child get, as they must receive the same amount of cards?

Example 26 (quotitive): Mariana has 15 sheets of paper and wants to form booklets with 5 sheets each. How many booklets can she form?

${ }^{5}$ In partitive division problems an initial quantity and the number of parts in which this amount should be distributed are given, and the size of each part should be found. In quotitive division problems, an initial quantity and the size of each part (quota) are given, and the number of parts in which the initial amount should be distributed should be found (Lautert \& Spinillo, 2002). 
As illustrated in Table 7, the most frequent type was partitive division problems (Group 1: 90.2\% and Group 2: 90\%).

\section{Table. 7}

Number and percentage (in parentheses) of type of division problems in each group of participants.

\begin{tabular}{ccc}
\hline Groups & \multicolumn{2}{c}{ Types of division problems } \\
Qurtitive & Quotitive \\
\cline { 2 - 3 } Group 1 & $\mathbf{3 7}$ & $\mathbf{4}$ \\
$(\mathrm{n}=41)$ & $(90.2)$ & $(9.8)$ \\
Group 2 & $\mathbf{3 6}$ & $\mathbf{4}$ \\
$(\mathrm{n}=40)$ & $(90)$ & $(10)$ \\
\hline
\end{tabular}

Note: Group 1: teachers of the $1^{\text {st }}$ and $2^{\text {nd }}$ grades of elementary school; Group 2: teachers of the $3^{\text {rd }}, 4^{\text {th }}$, and $5^{\text {th }}$ grades of elementary school.

In general, once again, the groups of teachers did not differ as to the types of problems they posed, since most of the problems of additive structure were of simple proportion one-to-many, and those of multiplicative structure were problems of partitive nature.

\section{DISCUSSIONS AND CONCLUSIONS}

Why investigate mathematical problems posed by teachers? Before answering this, it is necessary to answer another question: How important is mathematical problem posing for teaching? From the point of view of knowledge, as evidenced by research in the area, problem posing plays an important role in understanding the mathematical concepts, thus contributing to the knowledge of those who intend to develop such concepts in their students. As problem posing is ultimately part of problem solving, as emphasised by Elwan and Sultan (2016), another knowledge teachers acquired when they pose problems is to solve mathematical problems in general. Both acquisitions, knowledge about mathematical concepts and knowledge about problem solving, are gains for each individual, not just teachers. 
However, posing problems becomes crucial because mathematical problems are essential for concept formation (Vergnaud, 1990, 2003, 2017, 2019) and have an unquestionable didactic value (Onuchic \& Allevato, 2004; Pais, 2006). The didactic value of problems can be extended beyond their resolution, involving their formulation, as Spinillo et al. (2017) highlighted. The ability to pose problems is also a tool that contributes to teachers becoming able to critically analyse textbooks, identifying their limits and formulating problems that complement and deepen the activities proposed in the classroom, bringing them closer to the objectives they intend to achieve and to situations that make sense to their students (Chapman, 2011). We emphasise here that at no time we advocate that the teacher should replace the textbook with problems that her/himself may formulate. Rather, we intend to strengthen the relationship between the teacher and the textbook (and other didactic resources) in favour of increasingly efficient teaching practices.

After these considerations, it is then necessary to answer the question that started this session: Why investigate mathematical problems posed by teachers? One possible answer, among other plausible ones, is: because we need to know more about what the teacher knows about mathematical problems. The ability to formulate problems can be an indicator of the teachers' conception of what a problem is and what it means to do mathematics with their students, in general, and, specifically, about the mathematical concept involved in it, because every mathematical problem deals with one or more concepts that are intertwined in its resolution (Vergnaud, 1990, 2003, 2017, 2019). Another reason is that, despite its relevance, this issue is neglected in teacher education. In Brazil, problem posing is barely mentioned in documents that guide curricular proposals for the teaching of mathematics, and, in fact, it is not mentioned as a topic to be addressed in teacher education programs.

By bringing new information and resuming previous studies (Souza \& Magina, 2017; Spinillo et al., 2017), this investigation analysed the characteristics of additive and multiplicative problems formulated by teachers. As an additional objective, the study examined whether the characteristics of the problems would vary according to the school grade in which they taught. For this, two groups of participants were formed: teachers who taught in early school grades of elementary school, in which the teaching emphasises concepts of additive structure, and teachers who taught in more advanced school grades, in which the teaching focuses on concepts of multiplicative structure. 
Several characteristics were considered in the analysis of the problems the participants produced. The results systematically showed that neither the school grade in which the teacher taught, nor the type of operation requested in the instructions differentiated the problems they posed, which presented very similar features.

The first similarity was that problems were clearly formulated, with an unambiguous language, presenting the information necessary for their resolution. In most of them, the numerical information was contextualised, and the question of the problem was explicit, and it was possible to know accurately what should be sought. The conclusion was that the teachers of both groups were able to formulate suitable and possible problems for another person to solve.

The second similarity lies in the cognitive effort employed by those who would possibly solve the problems. It was found that the problems were very simple because they required only one step to be solved, that is, only one operation. Thus, regardless of the operation to be applied, the problems were elementary, without challenging the solver. It seems that the teachers' conception of a mathematical problem expressed the idea that for each problem, there is only one operation to be used. Spinillo and Magina (2004) comment on this notion, referring to it as one of the myths about the teaching and learning mathematics in the early grades. This conception, according to the authors, permeates classroom practices, leading students to make comments such as "This is a subtraction problem" "This is a multiplication problem". This conception opposes what Vergnaud $(1990,2003,2017,2019)$ claims, that a given situation may involve several mathematical concepts.

The third similarity identified was in the types of problems formulated. The results revealed that addition and subtraction problems were characterised as being, fundamentally, of composition and transformation type, while multiplication problems were of the simple one-to-many proportion type, and division ones were of the partitive type that is associated with the elementary notion of distribution. Two comments deserve to be made about these results. The first is that the problems posed are elementary and not challenging, as discussed previously. The second comment refers to the fact that there was little variability regarding the types of problems. These results were also documented by Spinillo et al. (2017), who state that the problems posed by the teachers covered a limited number of situations. Once again, teachers' conceptions of mathematical problems seem to drift apart from what Vergnaud (1983, 1990, 
2003, 2017, 2019) proposes: the mastery of mathematical concepts occurs through a wide variety of situations, since a single situation would be insufficient to encompass all the properties of concepts.

In general, it was observed that the pattern of results is the same in both groups, confirming what was seen in previous studies with teachers who taught from $1^{\text {st }}$ to $9^{\text {th }}$ grades of elementary school (Souza \& Magina, 2017; Spinillo et al., 2017). In other words, even working in more advanced school grades, teachers do not formulate more complex and diverse problems than those who teach in the early grades. The conclusion was that the activity of posing problems is limited and does not change according to the grade in which teachers teach. For there to be a change, it seems necessary fostering interventions specifically addressing this issue, such as those mentioned at the beginning of this article, in which teachers and prospective teachers showed to have improved their knowledge about mathematics problems.

The limitations observed seem to stem from the little familiarity that teachers have with the activity of formulating problems and the conception they have about mathematical problems in general. To overcome these limitations, it is necessary that they have a broad understanding of what a mathematical problem is, that they know the properties of the mathematical concept involved in the problems to be formulated, and the possible procedures that can be adopted to solve them. These points are part of the teaching knowledge that needs to be considered in teacher education.

To conclude, it is worth answering a challenging question that served as the title of Kilpatrick's chapter (1987): "Problem formulating: where do good problems come from?" The answer would be: they come from different sources, including the teachers themselves.

\section{AUTHORSHIP CONTRIBUTION STATEMENT}

N. T. A. contributed to formulating and applying the instrument adopted in the data collection, transcribing, organising, and analysing the data, reviewing the literature, and writing the article. A. G. S. contributed to the research idea, the development of the instrument adopted in the data collection, the analysis of the data, the literature review, and writing the article. S. L. L. contributed to organising the data, preparing tables, reviewing the literature, and standardising the final version of the text submitted to this journal. 


\section{DATA AVAILABILITY STATEMENT}

The data produced in the investigation will be made available by the first author upon request considered reasonable by the authors.

\section{ACKNOWLEDGEMENTS}

The authors are grateful to the following institutions: (i) Conselho Nacional de Desenvolvimento Científico e Tecnológico (CNPq) of the Brazilian Ministry of Science and Technology for the scholarship granted to the first author to complete a post-doctorate in the Post-Graduate Programme in Cognitive Psychology at the Federal University of Pernambuco; (ii) Coordenação de Aperfeiçoamento de Pessoal de Ensino Superior (CAPES) of the Brazilian Ministry of Education for the supporting given to the above mentioned post-graduate programme; and (iii) Fundação de Amparo à Ciência do Estado de Pernambuco (FACEPE) for the grant (Bolsa de Incentivo Acadêmico - BIA) awarded to Julia Barros do Nascimento. Julia earns our thanks for her participation in the organisation and partial analysis of the data. Her tireless willingness and interest in this research allowed the data to be analysed in a short time.

\section{REFERENCES}

Altoé, R. O \& Freitas, R. C. (2019). Formulação de problemas no campo conceitual multiplicativo: uma proposta para o ensino de multiplicação e divisão no eixo de produto de medidas. Revista de Educação Matemática e Tecnológica Iberoamericana - Em Teia, 10(3),1-23. http://dx.doi.org/10.23925/1983-3156.2018v21i2p105129

Elwan, A. \& Sultan, R. (2016). Mathematics problem posing skills in supporting problem solving skills of prospective teachers. In: Proceedings of the $40^{\text {th }}$ Conference of the International Group for the Psychology of Mathematics Education. (pp. 3-10). Szeged. 
Bonotto, C. (2013). Artifacts as sources for problem-posing activities. Springer: Educational Studies in Mathematics, 83(1), 37-55. https://www.jstor.org/stable/23434195

Brasil. (1997). Parâmetros Curriculares Nacionais terceiro e quarto ciclos do ensino fundamental: introdução aos parâmetros curriculares nacionais. MEC/SEF.

http://portal.mec.gov.br/seb/arquivos/pdf/ttransversais.pdf

Brasil. (2000). Parâmetros curriculares nacionais: ensino médio. MEC. http://portal.mec.gov.br/seb/arquivos/pdf/blegais.pdf

Brasil. (2020). Base Nacional Comum Curricular. 2017. http://basenacionalcomum.mec.gov.br

Brasil. (2020). Base Nacional Comum Curricular. Educação é a Base. MEC. http://basenacionalcomum.mec.gov.br/images/BNCC EI EF 110518 versaofinal site.pdf

Brown, S. I. \& Walter, M. I. (2005). The art of problem posing. Lawrence Erlbaum.

Brown, S. I. \& Walter, M. I. (1993). Problem posing: reflections and applications. Lawrence Erlbaum.

Chapman, O. (2011). Prospective elementary school teachers' ways of making sense of mathematical problem posing. In: Proceedings of the $35^{\text {th }}$ Conference of the International Group for the Psychology of Mathematics Education (pp.209-216), Ankara, Turkey.

Chica, C. (2001). Por que formular problemas? In: K. Smole, K. \& M. Diniz, M. (Orgs.). Ler, escrever e resolver problemas: habilidades básicas para aprender matemática (pp. 151-173). Artmed.

Crespo, S. (2003). Learning to pose mathematical problems: exploring changes in preservice teachers' practices. Springer: Educational Studies in Mathematics, 52, 243-270. https://doi.org/10.1023/A:1024364304664

Cunha, M. J. G. (2015). Elaboração de problemas combinatórios por professores de matemática do ensino médio. Recife: UFPE. $137 \mathrm{f}$. Dissertação (Mestrado em Educação Matemática e Tecnológica) Universidade Federal de Pernambuco, Recife. 
Dante, L. R. (2009). Formulação e resolução de problemas de matemática: teoria e prática. Ática.

English, L. (1997). The development of fifth-grade children's problem-posing abilities. Springer: Educational Studies in Mathematics, 34, 183-217. https://doi.org/10.1023/A:1002963618035

Freudenthal, H. (1973). Mathematics as an educational task. Reidel.

Gonzales, N. A. (1994). Problem posing: A neglected component in mathematics courses for prospective elementary and middle school teachers. School Science and Mathematics, 94(2), 78-84. https://doi.org/10.1111/j.1949-8594.1994.tb12295.x

Kilpatrick, J. (1987). Problem formulating: Where do good problems come from? In: A. H. Schoenfeld (Ed.). Cognitive science and mathematics education (pp. 123-147). Lawrence Erlbaum.

Lavy, I \& Shriki, A. (2007). Problem posing as a means for developing mathematical knowledge of prospective teachers. In: Proceedings of the $31^{\text {th }}$ Conference of the International Group for the Psychology of Mathematics Education (pp.129-136). Seoul, South Korea.

Lautert, S. L., Castro-Filho, J. \& Santana, E. R. S. (2017). Ensinando multiplicação e divisão do $1^{\circ}$ ao $3^{\circ}$ ano. Via Litterarum,

Lautert, S. L. \& Spinillo, A. G. (2002). As relações entre o desempenho em problemas de divisão e as concepções de crianças sobre a divisão [The Relations Between Performance on Division Problems and Children's Ideas About Division]. Brasília: Psicologia: Teoria e Pesquisa, 18(3), 237-246.

Lee, Y., Capraro, R. M, \& Capraro, M. M. (2018). Mathematics Teachers' Subject Matter Knowledge and Pedagogical Content Knowledge in Problem Posing. International Electronic Journal of Mathematics, 13(2), 75-90. https://doi.org/10.12973/iejme/2698

Leung, S. \& Silver, E. A. (1997). The role of task format, mathematics knowledge, and creative thinking on the arithmetic problem posing of prospective elementary school teachers. Springer: Mathematics Education Research Journal, 9(1), 5-24. https://doi.org/10.1007/BF03217299 
Lowrie, T. (2002). Young children posing problems: the influence of teacher intervention on the type of problems children pose. Mathematics Education Research Journal, 14( 2), 87-98.

Magina, S. M. P., Santos, A. \& Merlini, V. L. (2014). O raciocínio de estudantes do ensino fundamental na resolução de situações das estruturas multiplicativas [Primary students' reasoning in multiplicative structures problem solving]. Bauru: Ciência e Educação, 20, 517-533. https://doi.org/10.1590/1516$\underline{73132014000200016}$

Medeiros, K. \& Santos, A. J. B. (2007). Uma experiência didática com a formulação de problemas matemáticos. [A Didactic Experience with the Formulation of Mathematical Problems] Zetetiké, 15(28), 87-118. https://doi.org/10.20396/zet.v15i28.8647027

Morais, M. D. \& Teles, R. A. M. (2014). Grandezas e medidas no ciclo de alfabetização. Cadernos da TV Escola: Um salto para o futuro. Grandezas e medidas no ciclo de alfabetização. 8, 10-16. https://cdnbi.tvescola.org.br/contents/document/publicationsSeries/16 532008 14_MedidaseGrandezasnociclodaalfabetizacao.pdf

Onuchic, L. R. \& Allevato, N. S. G. (2004). Novas reflexões sobre o ensinoaprendizagem de matemática através da resolução de problemas. In: Bicudo, M. A. V \& Borba, M. C., (Orgs.). Educação matemática: pesquisa em movimento (pp. 213-231). Cortez.

Pelczer, I, Singer, F. M. E \& Voica, C. (2014). Improving problem posing capacities through inservice teacher training programs: challenges and limits. In: Proceedings of the $38^{\text {th }}$ Conference of the International Group for the Psychology of Mathematics Education and the $36^{\text {th }}$ Conference of the North American Chapter of the Psychology of Mathematics Education (pp.401-408). Vancouver, Canada.

Polya, G. (1995). A arte de resolver problemas. Interciência.

Ribeiro, M. \& Amaral, R. (2015). Early years prospective teachers ${ }^{e e}$ specialised knowledge on problem posing. In: Proceedings of the $39^{\text {th }}$ Conference of the International Group for the Psychology of Mathematics Education (pp. 81-88).Hobart, Australia. 
Sengul, S. \& Katranci, Y. (2014). Structured problem posing cases of prospective mathematics teachers: experiences and suggestions. International Journal on New Trends in Education and Their Implications, 5(4), 190-204. http://www.ijonte.org/FileUpload/ks63207/File/17..sengul.pdf

Silver, E. A. (1994). On mathematical problem posing. For the learning of Mathematics, 14(1), 19-28. http://www.jstor.org/stable/40248099

Singer, F. M., Ellerton, N. F. \& Cai, J. (2013). Mathematical problem posing. From research to effective practice. Springer.

Singer, F. M., Ellerton, N. F. \& Cai, J. (2013). Problem-posing research in mathematics education: new questions and directions. Educational Studies in Mathematics, 83(1), 1-7 https://doi.org/10.1007/s10649$\underline{013-9478-2}$

Souza, E. I. R. S. \& Magina, S. M. P. (2017). Concepção do Professor do Ensino Fundamental sobre Estruturas Multiplicativas. [The Conception of Elementary School Teachers Concerning Multiplicative Structures] Perspectivas da Educação Matemática, 10(24). 797- 815. https://periodicos.ufms.br/index.php/pedmat/article/view/2930/4163

Spinillo, A. G., Lautert, S., Borba, R. E. S. R., Santos, E. M. \& Silva, J. F. G. (2017). Formulação de Problemas Matemáticos de Estrutura Multiplicativa por Professores do Ensino Fundamental. [The Posing of Mathematical Problems Involving Multiplicative Structures by Elementary School Teachers] Rio Claro: Bolema, 31(59) 928-946.

Spinillo, A. G. \& Magina, S. (2004). Alguns 'mitos' sobre a educação matemática e suas consequências para o ensino fundamental. In: R. M. Pavanello (Org.). Matemática nas séries iniciais do ensino fundamental: a pesquisa e a sala de aula (pp. 7-35). Biblioteca do Educador Matemático.

Stoyanova, E. \& Ellerton, N. F. (1996). A framework for research into students' problem posing in school mathematics. In: P. Clarkson (Ed.). Technology in mathematics education (pp. 518-525). Mathematics Education Research Group of Australasia. 
Vergnaud, G. (1983). Multiplicative structures. In: R. A. Lesh \& M. Landau (Eds.). Acquisition of mathematics: concepts and process (pp.127174). Academic Press.

Vergnaud, G. (1990). La théorie des champs conceptuels. Grenoble, Recherches en Didactique des Mathématiques, 10, 133-171. http://www.numdam.org/article/PSMIR_1989_S6_47_0.pdf

Vergnaud, G. (2003). A gênese dos campos conceituais. In: E. P. Grossi (Org.). Por que ainda há quem não aprende? A teoria (pp.21-64). Vozes.

Vergnaud, G. (2009). A criança, a matemática e a realidade. UFPR.

Vergnaud,G. (2017). O que é aprender? Por que Teoria dos Campos Conceituais? E. P. Grossi (Org.). O que é aprender? O Iceberg da Contextualização - Teoria dos Campos Conceituais. GEEMPA. Coleção Teoria dos Campos Conceituais.

Vergnaud, G. (2019). Quais questões a teoria dos campos conceituais busca responder? Caminhos da Educação Matemática em Revista/Online, $9(1), 1-24$.

Zunino, D. L. (1995). A matemática na escola: aqui e agora. Artes Médicas. 
